\title{
PROFIL VULVA DAN SUHU TUBUH KAMBING PERANAKAN ETAWA PADA SINKRONISASI ESTRUS MENGGUNAKAN MEDROXY PROGESTERONE ACETATE DAN SUPLEMENTASI ZINC (Zn)
}

\author{
Muhammad Rosyid Ridlo ${ }^{1}$, Risa Ummami ${ }^{2}$, Naela Wanda Yusria Dalimunthe ${ }^{3}$, \\ Dhasia Ramandani ${ }^{4}$, Nur Ika Prihanani ${ }^{5}$, Morsid Andityas ${ }^{6}$, Tri Satya Mastuti Widi ${ }^{7}$ \\ 1,2,3,4,5,6 Program Studi Diploma Kesehatan Hewan, Departemen Teknologi Hayati \\ dan Veteriner, Sekolah Vokasi, Universitas Gadjah Mada, Indonesia. \\ ${ }^{7}$ Laboratorium Ternak Potong, Kerja dan Kesayangan, \\ Departemen Produksi Ternak, Fakultas Peternakan UGM. \\ Email: ${ }^{1}$ rosyidridlo@ugm.ac.id; ${ }^{2}$ risa.ummami@ugm.ac.id; ${ }^{3}$ naela.wanda@ugm.ac.id; \\ ${ }^{4}$ dhasia.r@ugm.ac.id; ${ }^{5}$ drh_nurika@ugm.ac.id; ${ }^{6}$ morsid.andityas@ugm.ac.id; \\ ${ }^{7}$ widi.tsm@ugm.ac.id
}

\begin{abstract}
Peranakan Etawa (PE) goat farming is one of the growing livestock sectors in Indonesia. Indonesia needs a sustainable breeding system that can guarantee the availability of goats. Estrus synchronization is a necessity that can help uniform the breeding time and manage the time of pregnancy and birth. Artificial estrus synchronization techniques that use a combination of Prosterone and Zinc minerals give good results of estrus synchronization in goats. The Aim of this research is to understand the combination efectiveness of estrus synchronization technique with progesterone acetate and Zinc supplementation. The design of this study used two treatment groups, each group consisting of three does PE goats. Estrus synchronization of experimental animals in treatment 1 and 2 was carried out using polyurethane sponge implant method which contained medroxi progesterone acetate $60 \mathrm{mg}$. Group 1 was given Sponge Progesterone for nine 9 days while giving Zinc (Zn) mineral supplement (Elemental Zn 20 mg, Kimia Farma) orally given 7 times. The frequency of Zinc administration every day begins during intra vaginal sponge insertion. Group 2 was treated same as group 1 with 14 days of implant time and 7 times of Zinc supplementation.The results showed that both treatments occurred estrus simultaneously with good estrus quality. Both treatments show the results of the estrus 8 score assessment with the estrus 3-9 range. The maximum estrus quality's value of group 2 was higher $(8.33 \pm 0.57)$ compared to group 1 ( $8.0 \pm 1.0)$. The estrus duration of group 2 occurs for 24 hours and group 1 for 7 hours. Estrus onset of Group 2 is earlier (58 hours) than group 1 (75 hours). Both treatment groups showed an increase in temperature at period of the occurrence of estrus. Body temperature during estrus time was $38.7 \pm 0.20{ }^{\circ} \mathrm{C}$ to $39.60 \pm$ $0.26{ }^{\circ} \mathrm{C}$. The conclusion of this study is that in both treatments of estrus synchronization using sponge progesterone and zinc supplementation can cause estrus synchronization effectively. The duration of estrus in group 1 (9 days of implant) was Shorter than group 2 (14 days of implant). The onset of estrus time of group 1 (9 days of implant) was longer than Group 2 (14 days of implant). The body temperature of the experimental animals increases with the occurrence of estrus.
\end{abstract}

Keywords: estrus synchronization, medroxi progesterone acetate, zinc 
Muhammad Rosyid Ridlo, Risa Ummami, Naela Wanda Yusria Dalimunthe, Dhasia Ramandani, Nur Ika Prihanani, Morsid Andityas, Tri Satya Mastuti Widi Profil Vulva Dan Suhu Tubuh Kambing Peranakan Etawa pada Sinkronisasi Estrus Menggunakan Medroxy Progesterone

Acetate dan Suplementasi Zinc (Zn)

\section{PENDAHULUAN}

Peternakan sebagai sektor hulu pemasok protein hewani hendaknya memperhatikan keberlanjutan produksi hasil ternaknya. Keberlanjutan sebuah peternakan erat kaitannya dengan perkembangbiakan hewan itu sendiri. Reproduksi hewan berperan penting dalam siklus perkembangbiakan hewan dan keberlanjutan sebuah peternakan yang berorientasi pada breeding. Kambing Peranakan Etawa (PE) memiliki keunggulan penting yaitu dapat dimanfaatkan sebagai kambing penghasil susu dan sebagai kambing pedaging untuk dikonsumsi (Kurniasih et al., 2013). Keunggulan yang tidak kalah penting adalah kambing PE merupakan salah satu jenis kambing kontes yang bernilai ekonomis tinggi. Kulit kambing dapat dimanfaatkan sebagai bahan kerajinan, souvenir atau diolah di industri pengolahan kulit hewan. Para penghobi kambing menjadikan kambing PE sebagai hewan kesayangan atau kambing kontes yang sangat banyak diminati oleh para penghobi kambing. Keindahan performa kambing kontes yang ditentukan berdasarkan nilai tertentu antara lain performa, warna dan keserasian membuat kambing kontes PE sangat berpotensi untuk dikembangkan. Biaya pemeliharaan setiap ekor tidak membutuhkan banyak modal, dewasa kelamin yang relatif dicapai pada usia 9 bulan, pemeliharaan relatif mudah, resiko penyakit yang rendah, jumlah anak perkelahiran (litter size) yang lebih dari 1, kidding interval 7-8 bulan, masa kebuntingan \pm 150 hari mendukung sebuah usaha peternakan kambing merupakan usaha yang menjanjikan. Kambing PE tidak membutuhkan lahan yang luas, tenaga kerja sedikit dan kemampuan adaptasi yang tinggi terhadap lingkungan dan pakan yang terbatas (Mehmood et al., 2011). Hal tersebut mendukung sebaran ternak tersebut yang hampir merata di seluruh Indonesia. Keuntungan yang sangat banyak dari kambing PE membuat banyak kalangan pengusaha peternakan tertarik beternak kambing PE.

Sejalan dengan banyaknya kebutuhan kambing PE baik sebagai penghasil susu, daging maupun sebagai kambing kontes perlu diperhatikan keberlanjutan reproduksinya. Keberlanjutan pembibitan peternakan menjadi keharusan dalam usaha peternakan yang berorientasi pada produksi ternak, sehingga suplai hewan maupun produk pangan asal hewan senantiasa terjaga. Manajemen breeding pada kambing PE yang baik dan sistem yang mudah dilaksananakan akan sangat membantu peternak untuk menjalankan usaha peternakannya. Teknologi reproduksi berperan penting dalam program breeding di sebuah peternakan. Aplikasi teknologi reproduksi di ruang lingkup peternakan hendaknya dimanfaatkan sebaik mungkin oleh peternak di Indonesia. 
Manajemen reproduksi yang dipadukan dengan teknologi reproduksi terapan akan menghasilkan role model tepat guna yang mampu meningkatkan kualitas peternakan baik dari sisi kualitas maupun kuantitas.

Kondisi terkini peternakan Indonesia sudah banyak peternak yang memiliki peternakan skala menengah dengan populasi di atas 100 ekor per peternakan. Tingkat pendidikan peternak juga banyak yang memiliki jenjang pendidikan strata satu. Meskipun bukan berlatar belakang dari jurusan peternakan namun pola pikir sarjana memberikan dampak positif yang signifikan terhadap cara pandang peternak serta pengelolaan usaha peternakan. Pemahaman yang kuat dalam hal reproduksi kambing sangat berperan besar dalam kesuksesan program perkembangbiakan sebuah usaha peternakan. Pengetahuan siklus estrus (estrus) kambing dan ciriciri utama kambing estrus hendaknya difahami dengan baik oleh peternak. Kambing yang sedang mengalami masa estrus merupakan satu satunya waktu yang paling tepat untuk proses perkawinan. Kambing betina jika tidak mengalami estrus maka tidak akan kooperatif melakukan proses perkawinan (Ridlo et al., 2015). Waktu estrus merupakan waktu ketika sel telur (oocyte) sudah siap untuk diovulasi kan yang selanjutnya siap untuk difertilisasi (dibuahi) apabila terjadi proses perkawinan (Cochran, 2011). Ciri kambing estrus yang siap untuk dikawinkan antara lain hewan betina akan mendekati atau mengarahkan badannya menuju pajantan, ekornya dikibaskan dengan ritmik dan relatif lebih cepat dibandingkan saat tidak estrus, hewan betina telihat bergairah terhadap pejantan, diam saat didekati dan dinaiki pejantan. Keadaan vulva apabila dibuka akan terlihat berwarna kemerahan, terjadi pembengkakan ukuran, dan mengeluarkan lendir bening yang jauh lebih banyak dibandingkan pada saat tidak mengalami estrus. Pemeriksaan secara ultrasonografis menggunakan ultrasonografi terlihat folikel sel telur yang berukuran lebih besar dibandingkan folikel lainya di dalam ovarium kambing. Secara normal folikel akan berkembang seiring siklus estrus pada kambing, namun pada saat estrus terdapat folikel yang berkembang secara dominan dibanding ukuran folikel lainya yang kemudian disebut sebagai folikel de graaf. Keberadaan folikel de graaf di ovarium kanan dan atau kiri pada saat tertentu menjadi tanda terjadinya estrus pada kambing. (Ridlo et al., 2015).

Proses perkawinan dikatakan berhasil apabila pejantan dapat melakukan intromisi ke dalam vulva dilanjutkan fase klimaks perkawinan dengan ciri utama ejakulasi cairan semen, sehingga ejakulat semen yang mengandung spermatozoa berhasil dipancarkan ke dalam saluran vagina. Spematozoa yang telah diejakulasikan akan bergerak menuju saluran cerviks dan uterus, 
Muhammad Rosyid Ridlo, Risa Ummami, Naela Wanda Yusria Dalimunthe, Dhasia Ramandani, Nur Ika Prihanani, Morsid Andityas, Tri Satya Mastuti Widi Profil Vulva Dan Suhu Tubuh Kambing Peranakan Etawa pada Sinkronisasi Estrus Menggunakan Medroxy Progesterone

Acetate dan Suplementasi Zinc (Zn)

kemudian sampailah di area oviduct untuk proses fertilisasi/pembuahan. Hasil penyatuan spermatozoa dan sel telur pada proses fertilisasi akan berlanjut menjadi embryo yang kemudian akan berkembang menjadi fetus (Cochran, 2011).

Secara alami waktu estrus merupakan bagian dari fase estrus kambing yang terpola berulang pada setiap 18-22 hari. Sinkronisasi estrus merupakan keniscayaan yang dapat membantu peternak dalam menyeragamkan waktu perkawinan dan membantu mengatur waktu kebuntingan serta kelahiran (Zaenuri dan Rodiah, 2016). Teknik sinkronisasi buatan menggunakan kombinasi Progsteron dan mineral $Z n$ sudah dilakukan dan memberikan hasil sinkronisasi estrus yang baik pada kambing (Adriani et al., 2004; Ridlo et al, 2015). Perlu penyempurnaan dalam aplikasinya supaya waktu penggunaan bisa lebih efisien dan optimal. Penelitian ini bertujuan untuk mengetahui efektifitas kombinasai teknik penggunaan spons progesterone dan $\mathrm{Zn}$ pada kambing PE betina pada penggunaan implant spons progesterone 9 hari dan 14 hari.

\section{MATERI DAN METODE PENELITIAN}

Materi yang digunakan dalam penelitian ini adalah hewan kambing betina dengan usia 2-4 tahun yang pernah melahirkan. Kondisi kambing betina pada saat disinkronisasi estrus dalam keadaan tidak bunting. Hewan coba ditempatkan di kandang panggung, setiap hewan coba dikandangkan dalam satu ruangan satu individu. Hewan betina dipisah antara pejantan dan hewan betina. Kandang panggung memiliki fasilitas tempat pakan dan minum yang adlibitum. Frekuensi pakan dilakukan seperti kebiasaan sebelum perlakuan. Selama perlakuan dalam penelitian ini tidak ada perubahan pola dan jenis pemberian pakan maupun minum. Bahan yang digunakan antara lain spuit (Terumo), kapas, alkohol 70\%, spons intra vaginal, sarung tangan, gel pelumas untuk vagina, thermometer digital, lampu senter, speculum, gunting pinset dan aplikator spons intra vaginal.

Pembuatan spons intra vaginal menggunakan spons polyurethane dengan ukuran $4 \mathrm{~cm} \times 4$ $\mathrm{cm}$ x $4 \mathrm{~cm}$. Spons polyurethane dibentuk dengan bentuk tumpul supaya lebih sesuai dan nyaman pada saat dimasukkan ke dalam saluran vagina. Spons polyurethane yang telah berbentuk dipasangkan tali nilon sepanjang $20 \mathrm{~cm}$ dengan bantuan jarum. Proses selanjutnya adalah pencucian dan pengeringan spons polyurethane selama 12 jam. Bahan spon polyurethane yang 
telah kering kemudian di tetesi larutan hormone medroxi progesterone acetate 60 mg kemudian dikeringkan (Zaenuri dan Rodiah, 2016). Alat sinkronisasi buatan berupa spons progesterone yang telah kering disimpan di dalam palstik yang bersih dan siap untuk digunakan.

Penggunaan spons progesterone secara intra vagina dilakukan dengan bantuan aplikator berupa silinder yang terbuat dari bahan pipa PVC (Polyvinyl Chloride). Aplikator spons progesterone dibuat sepanjang $30 \mathrm{~cm}$ untuk membantu memasukkan spons progesterone ke dalam saluran vagina. Cara penggunaannya dilakukan dengan membersihkan dengan cairan desinfektan berupa alkohol $70 \%$. Aplikator yang telah didesinfektan dengan alkohol kemudian dibasahi dengan cairan pelumas vagina. Langkah selanjutnya adalah dengan memasukkan spons progesterone ke dalam pipa aplikator. Spons progesterone yang telah siap pakai, diinsersikan ke dalam vagina secara perlahan dimasukkan dengan hati-hati ke dalam saluran vagina. Pipa aplikator dimasukkan hingga ke ujung mulut serviks. Spons progesterone didorong menggunakan stick pipa PVC (Polyvinyl Chloride) (yang berdiameter lebih kecil) hingga spons progesterone berada di ujung mulut serviks. Tahapan selanjutnya adalah menarik aplikator dan stick secara perlahan, sehingga spons progesterone berhasil masuk berada di ujung serviks dalam saluran vagina. Pemasangan hewan coba dipegang oleh seorang asisten supaya kambing terkendali dan tidak banyak bergerak.

Desain penelitian pada penelitian ini dilakukan dengan menggunakan dua macam Grup perlakuan. Tahap persiapan dilakukan pemilihan kambing PE betina yang pernah beranak dan dalam kondisi tidak bunting usia 2-4 tahun. Kambing PE yang telah diseleksi dikelompokkan secara acak menjadi dua Grup perlakuan, masing-masing Grup terdiri dari tiga ekor kambing PE betina. Hewan coba yang telah dikelompokkan kemudian dikandangkan secara berkelompok dan diberi perlakuan yang seragam selama 20 hari termasuk pemberian vitamin dan obat cacing. Pemberian obat cacing telah rutin diberikan pada hewan coba oleh pengelola Laboratorium Ternak Potong, Kerja dan Kesayangan Fakultas Peternakan Universitas Gadjah Mada.

Sinkronisasi estrus hewan coba pada Grup 1 dan 2 dilakukan dengan metode implant polyurethane sponge. Spons progesterone merupakan Spons yang telah berisi medroxi progesterone acetate $60 \mathrm{mg}$ yang dimasukkan secara intravaginal dengan periode implant sesuai dengan jenis perlakuan. Grup perlakuan I kambing betina diberi perlakuan implant sinkronisasi spons progesterone selama 9 hari. Pemberian suplemen mineral Zn (Elemental Zn 20 mg, Kimia Farma) per oral diberikan sebanyak 7 kali, setiap hari sejak pemasangan intra vaginal sponge. 
Muhammad Rosyid Ridlo, Risa Ummami, Naela Wanda Yusria Dalimunthe, Dhasia Ramandani, Nur Ika Prihanani, Morsid Andityas, Tri Satya Mastuti Widi Profil Vulva Dan Suhu Tubuh Kambing Peranakan Etawa pada Sinkronisasi Estrus Menggunakan Medroxy Progesterone

Acetate dan Suplementasi Zinc (Zn)

Grup perlakuan II diberikan perlakuan seperti Grup 1 dengan waktu implant selama 14 hari dan pemberian $Z n$ sebanyak 7 kali, dengan frekuensi pemberian $Z n$ dua hari sekali.

Penelitian penggunaan spons progesterone pada kambing menunjukkan tanda-tanda estrus yang berupa kemunculan lendir, warna vulva berwarna kemerahan, dan bengkak pada penampakan vulva kambing. Spons progesterone dilepaskan dari vulva secara manual dengan bantuan alat speculum. Pengamatan kualitas estrus kambing yang disinkronisasi estrus dilakukan pada rentang waktu pagi, siang dan malam hari. Pelaksanaan pengamatan dilakukan pada jam 07.00 pagi, 14.00 siang dan 21.00 malam hari waktu indonesia bagian barat (WIB). Hal ini dilakukan untuk mengamati perubahan gejala estrus yang muncul pada kambing perlakuan. Vulva kambing diamati secara manual dengan membuka bagian labia mayora pada vulva kambing betina. Waktu pengamatan dimulai pada rentang waktu 20 jam pasca pelepasan spons progesterone yang bertepatan pada pagi hari pukul 07.00 (WIB). Pengamatan selanjutnya dilakukan secara berkelanjutan pada selang waktu 27, 34, 44, 51, 58, 68, 75, 82, 92, 99, 106 dan 116 jam pasca pelepasan spons progesterone.

Penulis mengkategorikan kualitas estrus merujuk pada penelitian yang dilakukan Zaenuri dan Rodiah (2016) dengan beberapa modifikasi. Pengamatan estrus berdasar warna mukosa vulva, keberadaan lendir dan kebengkakan. Kriteria warna merah dibedakan menjadi tiga (3) tingkatan penilaian. Skor terendah dinilai dengan skor 1 apabila warna mukosa vulva terlihat merah muda/pink, seperti keadaan normal. Skor 2 diberikan pada keadaan warna mukosa lebih merah/pink tua, sedangkan skor 3 diberikan pada keadaan warna cenderung kemerahan dan terlihat jelas perbedaan dengan skor 2. Penilaian pada status lendir dibedakan menjadi tiga (3) macam. Skor 1 diberikan pada keadaan lendir yang normal lembab tidak berlebihan. Skor 2 diberikan pada saat terdapat lendir berlebih, namun keberadaan lendir masih di daerah mukosa vulva. Skor 3 diberikan pada kondisi vlva yang mengeluarkan lendir berlebih, lendir banyak dan keluar hingga berleleran di luar vulva dan atau ada bekas lendir yang telah mengering. Status kebengkakan juga dibagi menjadi tiga (3) macam penilaian. Skor 1 diberikan apabila tidak ada pembengkakan pada vulva. Vulva yang mengalami perubahan bentuk yang lebih besar daripada keadaan normal, tekstur keriput sudah mulai tidak jelas diberikan skor 2. Skor 3 diberikan apabila terlihat vulva membesar, seperti ada timbunan cairan pembengkakan sehingga keriput vulva tidak jelas (Tabel 1). 
Dasar penggunaan spon progesterone selama 9 hari diadopsi dari penelitian yang menggunakan new CIDR vaginal device (Eazi-Breed CIDR, InterAg, New Zealand) yang berisi $0.3 \mathrm{~g}$ progesterone dengan panambahan $75 \mathrm{~g}$ d-cloprostenol (Ciosin, Coopers, Brazil) and $300 \mathrm{IU}$ equine chorionic gonadotropin (eCG; Novormon, Syntex, Argentina) (Nogueira et al., 2011). Hasil penelitian tersebut mampu memberikan hasil keseragaman estrus $100 \%$. Penelitian ini menggunakan efisiensi penggunaan waktu yang lebih pendek dengan kombinasi pemberian mineral $Z n$ yang diberikan bersamaan dengan periode pemasangan spon intra vagina. Pengamatan kualitas estrus dilakukan secara manual secara visual. Pengukuran suhu badan diukur dengan menggunakan thermometer digital. Hasil penelitian selanjutnya dianalisis secara deskriptif.

\section{HASIL DAN PEMBAHASAN.}

\section{Skor Kualitas Estrus.}

Penilaian skor estrus berdasarkan kriteria yang telah ditampilkan pada Tabel 1. Vulva kambing pada setiap pengamatan dinilai berdasar kan tiga (3) kriteria, yaitu warna mukosa, keberadaan lendir dan warna mukosa (Siregar, 2009). Penilaian pada tiga (3) kriteria tersebut kemudian dijumlahkan sehingga menjadi skor akumulatif pada setiap penilaian/ekor/waktu pengamatan. Pengamatan kualitas estrus dengan metode seperti yang telah di jelaskan pada paragraf di atas telah disajikan pada Table 2. Waktu pengamatan (jam pengamatan) pada Grup 2 dilakukan seperti pengamatan (jam pengamatan) pada Grup 1.

\section{Tabel 1. Kriteria Penilaian Estrus Kambing Pasca Pelepasan Spons Progesterone}

\begin{tabular}{lcl}
\hline Kriteria & Skor & \\
\hline Warna mukosa & 1 & Warna mukosa normal merah muda/pink \\
& 2 & Warna mukosa lebih merah dari mukosa normal/pink tua \\
& 3 & Warna mukosa cenderung kemerahan \\
\hline Keberadaan & 1 & Lendir normal pada mukosa \\
lendir & 2 & Lendir berlebih, masih di area vulva \\
& 3 & Lendir benyak, keluar di area vulva, ada bekas leleran di sekitar vulva \\
\hline Kebengkakan & 1 & Tidak ada pembengkakan \\
& 2 & Terdapat perubahan bentuk lebih besar, keriput vilva mulai tidak jelas \\
& 3 & Vulva tampak membesar, terlihat seperti ada timbunan cairan, keriput vulva tidak jelas \\
\hline
\end{tabular}

Berdasar hasil pengamatan terlihat bahwa pada Grup 1 memiliki skor 3,33 \pm 0,57 pada jam ke-20 pasca pelepasan spons progesterone. Secara berurutan pada jam ke: 27; 34; 44; 51; 58; dan 
Muhammad Rosyid Ridlo, Risa Ummami, Naela Wanda Yusria Dalimunthe, Dhasia Ramandani, Nur Ika Prihanani, Morsid Andityas, Tri Satya Mastuti Widi Profil Vulva Dan Suhu Tubuh Kambing Peranakan Etawa pada Sinkronisasi Estrus Menggunakan Medroxy Progesterone

Acetate dan Suplementasi Zinc (Zn)

68 adalah: $3,33 \pm 0,57 ; 3,33 \pm 0,57 ; 3,67 \pm 0,57 ; 3,67 \pm 0,57 ; 4,67 \pm 2,08$ dan $5,33 \pm 1,52$. Nilai kualitas estrus pada jam ke 20 hingga 68 masih berada di bawah nilai 6 . Hal ini terlihat pada saat pengamatan perubahan terhadap warna vulva, kebengkakan, dan keberadaan lendir masih belum terlihat perbedaan yang nyata. Deskripsi pada penilaian dengan skor 5 ada beberapa perubahan namun tidak secara keseluruhan dari ketiga kriteria, yaitu merah, bengkak dan berlendir. Hal yang terjadi adalah munculnya lendir yang mulai banyak namun masih berada di area vulva sehingga poin yang diperoleh adalah 2. Lendir yang berlebih kadang kala tidak bersamaan dengan munculnnya warna kemerahan atau kebengkakan. Kondisi ini menyebabkan nilai skor estrus tidak maksimal sehingga nilai keseluruhan masih berkisar antara 3 hingga 5. Kuantitas lendir pada individu yang berbeda dapat terjadi. Kuantitas lendir tersebut dapat disebabkan oleh status nutrisi, kuantitas lendir sebagai sifat fisik mempunyai kandungan yang berupa air, protein, lemak, karbohidrat dan mineral (Zaenuri dan Rodiah, 2016).

Perubahan vulva Grup 1 mulai terlihat pada pada jam ke-75 hingga 82. Nilai kualitas estrus terlihat meningkat dengan skor 7,67 0,57 dan $8,0 \pm 1,0$ berturut turut pada pengamatan jam ke75 dan 82 . Nilai 7 hingga 8 dapat dikategorikan estrus karena tanda-tanda estrus sudah tampak secara jelas. Biasanya keberadaan lendir akan lebih nyata hingga leleran lendir meluas ke luar area vulva. Skor pada saat lendir berlebih hingga ke luar area vulva dan terdapat bekas lendir yang mengering diberikan skor 3. Kebengkakan juga terlihat dengan adanya tanda-tanda perbedaan nyata pada kulit luar vulva yang sudah mulai tidak tampak jelas kerutan pada lipatan labia mayora. Warna mucosa yang menunjukkan merah segar pada vulva terlihat pada kambing betina yang estrus dengan sempurna. Penilaian warna mucosa yang merah dikategorikan dengan skor 3. Pengamatan pada pemasangan spons progesterone selama 9 hari menunjukkan sinkronisasi estrus terjadi pada jam ke-75 hingga 82 selama 7 jam.

Hasil pengamatan kualitas estrus pada jam ke : 92; 99; 106 dan 116 menunjukkan masingmasing secara beurutan adalah : 4,67 $\pm 1,52 ; 4,33 \pm 1,15 ; 4,33 \pm 1,52$ dan $3,67 \pm 0,15$. Secara umum nilai tersebut masih berada di bawah nilai skor yang dikategorikan estrus. Rentang skor penilaian kualitas estrus yang baik adalah 7 hingga 9. Gambaran kualitas estrus pada skor 7 sudah terlihat perubahan tanda-tanda estrus pada masing-masing kriteria. Perubahan warna, keberadaan lendir dan kebengkakan akan cenderung terlihat perbedaannya pada rentang skor estrus tersebut. Hasil pada pengamatan jam ke : 92; 99; 106 dan 116 menunjukkan keadaan kambing pada fase 
penurunan kualitas estrusnya. Fase ini merupakan fase pasca estrus pada kambing, biasanya kambing betina sudah sulit untuk dikawinkan (Ridlo et al., 2015; (Siregar, 2009)).

Pengamatan pada Grup 2 menunjukkan skor pada jam ke : 20, 27, 34, 44, 51, 58, 68, 75, 82, 92, 99, 106 dan 116 jam pasca pelepasan spons progesterone secara berturut turut adalah: $3,33 \pm 0,57 ; \quad 4,0 \pm 0,0 ; 4,33 \pm 0,57 ; \quad 5,33 \pm 0,57 ; \quad 5,66 \pm 0,57 ; \quad 6,33 \pm 1,15 ; \quad 7,66 \pm 0,57 ; \quad 8,33 \pm 0,57$; $7,66 \pm 2,31 ; 5,66 \pm 1,15 ; 6,0 \pm 1,0 ; 5,33 \pm 0,57$ dan $3,33 \pm 0,57$. Berdasar hasil pengamatan terlihat bahwa pada perlakuan Grup 2 memiliki skor kualitas estrus yang meningkat sejak 24 jam pasca pelepasan spons progesterone. Pengamatan pada jam ke : 20; 27; 34; 44 dan 51 pasca pelepasan spons progesterone secara berurutan adalah: 3,33 $\pm 0,57 ; 4,0 \pm 0,0 ; 4,33 \pm 0,57 ; 5,33 \pm 0,57$; $5,66 \pm 0,57$ dan $6,33 \pm 1,15$. Secara keseluruhan nilai kualitas estrus pada jam ke 20 hingga 58 masih berada di bawah nilai 7. Kondisi yang terlihat pada saat pengamatan perubahan terhadap warna vulva, kebengkakan, dan keberadaan lendir masih belum terlihat perbedaan yang nyata. Perubahan mulai terlihat pada jam ke 58 dimana skor kualitas estrus 6,33 $\pm 1,15$. Kondisi vulva sudah mulai tampak berlendir, mukosa memerah dan sedikit tanda kebengkakan namun belum maksimal, sehingga skoor penilaian estrus masih berkisar antara 5 dan 6. Keadaan pada pengamatan ini kambing betina sudah telihat mulai masuk pada tahap awal estrus sehingga kecenderungannya akan mengalami kenaikan kadar estrogen dalam darahnya (Ridlo et al., 2015; Siregar, 2009).

Tanda-tanda estrus hewan coba Grup 2 mulai teramati pada jam ke-58 hingga 99. Nilai kualitas estrus terlihat meningkat dengan skor $6,33 \pm 1,15 ; 7,66 \pm 0,57 ; 8,33 \pm 0,57$ dan $7,66 \pm 2,31$ berturut turut pada pengamatan jam ke-58; 68; 75 dan 82 . Nilai kualitas estrus terlihat lebih tinggi pada jam tersebut. Keberadaan lendir lebih nyata, wara mukosa lebih kemerahan dan kebengkakan terlihat. Hasil pengamatan kualitas estrus pada jam ke: 92; 99; 106 dan116

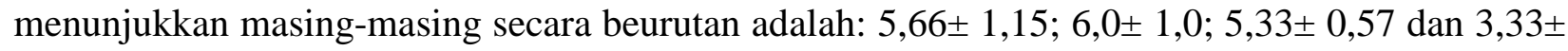
0,57. Nilai tersebut cenderung lebih rendah dibanding pada fase estrus. Pengamatan secara visual menunjukkan kemunculan kualits ciri-ciri estrus yang semakin berkurang. Hal ini menunjukkan fase pasca estrus. Secara keseluruhan pada perlakuan Grup 2 terjadi sinkronisasi estrus sejak pada jam ke-58 hingga jam 82 selama 24 jam. Penggunaan Pregnant Mare Serum Gonadoteropin (PMSG) yang dilakukan sebagai perlakuan saat sinkronisasi estrus memperlihatkan tanda-tanda estrus 34 jam, sementara pada kambing percobaan yang diperlakukan sebagai control menunjukkan tanda-tanda estrus 68 jam pasca perlakuan (Machiya et al., 2011). Respon estrus 
Muhammad Rosyid Ridlo, Risa Ummami, Naela Wanda Yusria Dalimunthe, Dhasia Ramandani, Nur Ika Prihanani, Morsid Andityas, Tri Satya Mastuti Widi Profil Vulva Dan Suhu Tubuh Kambing Peranakan Etawa pada Sinkronisasi Estrus Menggunakan Medroxy Progesterone

Acetate dan Suplementasi Zinc (Zn)

pada kambing dengan perlakuan spons progesterone memiliki variasi yang sangat besar tergantung breed, perlakuan ikutan, manjemen, dan system kawin (Mehmood et al., 2011).

\section{Durasi dan Onset Estrus.}

Durasi estrus merupakan lama waktu estrus yang teramati selama kejadian estrus. Rentang waktu durasi estrus pada Grup 1 terjadi selama kurang lebih 7 jam, sedangkan pada Grup 2 terjadi estrus selama 24 jam. Onset estrus merupakan waktu yang dibutuhkan sejak pelaksanaan sinkronisasi estrus dalam hal penelitian ini dimulai sejak pelepasan spons hingga pertama kali tanda-tanda estrus muncul. Waktu onset estrus pada Grup 1 mulai muncul tanda estrus pada jam ke-75 sedangkan pada Grup 2 pada jam ke-58. Hasil penelitian ini berbeda dengan penelitian penggunaan spons progesterone selama 11 hari yang ditambah dengan injeksi equine equine chorionic gonadotropin (eCG) $400 \mathrm{IU}$ dan cloprostenol $0.075 \mathrm{mg}$. hasil penelitian tersebut menunjukkan estrus terdetesi sejak 12-24 jam pasca pelepasan spons (Mehmood et al., 2011). Durasi estrus pada kambing bervariasi dilaporkan pada kambing Black Bengal antara 36 dan 48 jam (Machiya et al., 2011), masa durasi estrus pada kambing Savanna Brown Nigeria selama 21 26 jam (Kawu et al., 2015)

Hasil penelitian ini menunjukkan dua perlakuan terjadi estrus secara bersamaan dengan kualitas estrus yang baik. Kedua perlakuan menunjukkan hasil penilaian skor estrus delapan (8). Nilai maksimal kualitas estrus Grup 2 lebih tinggi $(8,33 \pm 0,57)$ dibandingkan dengan Grup 1 $(8,0 \pm 1,0)$. Durasi Grup 2 juga lebih panjang terjadi selama 24 jam dan Grup 1 selama 7 jam. Waktu onset Grup 2 lebih cepat (58 jam) dibandingkan Grup 1 (75 jam) (Tabel 2).

Gambaran kurva skor etrus secara keseluruhan mulai meningkat pada jam ke-27. Kedua perlakuan menunjukkan peningkatan pada jam ke-27 selanjutnya berturut turut meningkat hingga mencapai puncaknya. Kedua perlakuan terlihat mengalami estrus secara seragam di masingmasing kelompok perlakuan. Puncak kualitas estrus dengan nilai skor 8 tercapai pada jam ke-82. Puncak estrus pada Grup 2 terjadi lebih awal yaitu pada jam ke-75. Nilai maksimal estrus pada

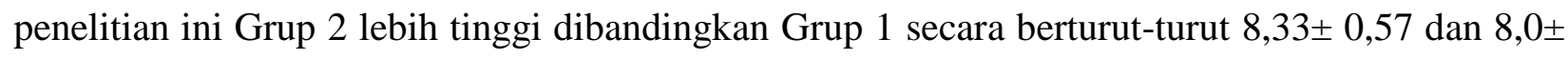
$1,0$. 
Tabel 2. Penilaian Skor Estrus Setelah Sinkronisasi Estrus

\begin{tabular}{|c|c|c|c|c|c|c|c|c|c|c|c|c|c|}
\hline & \multicolumn{13}{|c|}{ Skor estrus setelah sinkronisasi estrus } \\
\hline & $\begin{array}{c}20 \\
\text { jam }\end{array}$ & $\begin{array}{c}27 \\
\text { jam }\end{array}$ & $\begin{array}{c}34 \\
\text { jam }\end{array}$ & $\begin{array}{c}44 \\
\text { jam }\end{array}$ & $\begin{array}{l}51 \\
\text { jam }\end{array}$ & $\begin{array}{c}58 \\
\text { jam }\end{array}$ & $\begin{array}{c}68 \\
\text { jam }\end{array}$ & $\begin{array}{c}75 \\
\text { jam }\end{array}$ & $\begin{array}{c}82 \\
\text { jam }\end{array}$ & $\begin{array}{l}92 \\
\text { jam }\end{array}$ & $\begin{array}{c}99 \\
\text { jam }\end{array}$ & $\begin{array}{l}106 \\
\text { jam }\end{array}$ & $\begin{array}{l}116 \\
\text { jam }\end{array}$ \\
\hline $\begin{array}{c}\text { Grup } \\
1\end{array}$ & $\begin{array}{c}3,33 \pm \\
0,57\end{array}$ & $\begin{array}{c}3,33 \pm \\
0,57\end{array}$ & $\begin{array}{c}3,33 \pm \\
0,57\end{array}$ & $\begin{array}{c}3,67 \pm \\
0,57\end{array}$ & $\begin{array}{c}3,67 \pm \\
0,57\end{array}$ & $\begin{array}{c}4,67 \pm \\
2,08\end{array}$ & $\begin{array}{c}5,33 \pm \\
1,52\end{array}$ & $\begin{array}{c}7,67 \pm \\
0,57\end{array}$ & $\begin{array}{c}8,0 \pm \\
1,0\end{array}$ & $\begin{array}{c}4,67 \pm \\
1,52\end{array}$ & $\begin{array}{c}4,33 \pm \\
1,15\end{array}$ & $\begin{array}{c}4,33 \pm \\
1,52\end{array}$ & $\begin{array}{c}3,67 \pm \\
0,15\end{array}$ \\
\hline $\begin{array}{c}\text { Grup } \\
2\end{array}$ & $\begin{array}{c}3,33 \pm \\
0,57\end{array}$ & $\begin{array}{l}4,0 \pm \\
0,0\end{array}$ & $\begin{array}{c}4,33 \pm \\
0,57\end{array}$ & $\begin{array}{c}5,33 \pm \\
0,57\end{array}$ & $\begin{array}{c}5,66 \pm \\
0,57\end{array}$ & $\begin{array}{c}6,33 \pm \\
1,15\end{array}$ & $\begin{array}{c}7,66 \pm \\
0,57\end{array}$ & $\begin{array}{c}8,33 \pm \\
0,57\end{array}$ & $\begin{array}{c}7,66 \pm \\
2,31\end{array}$ & $\begin{array}{c}5,66 \pm \\
1,15\end{array}$ & $\begin{array}{c}6,0 \pm \\
1,0\end{array}$ & $\begin{array}{c}5,33 \pm \\
0,57\end{array}$ & $\begin{array}{c}3,33 \pm \\
0,57\end{array}$ \\
\hline
\end{tabular}

Fase penururnan skor penilaian estrus mulai teramati menurun pada jam 92 hingga jam ke116. Pengamatan pada kedua Grup menunjukkan nilai skor estrus sudah seperti fase kambing betina yang tidak estus pada Grup $1(3,67 \pm 0,15)$ dan Grup $2(3,33 \pm 0,57)$. Secara keseluruhan perubahan ini menunjukan fase sinkronisasi estrus terdiri dari tiga fase yaitu fase peningkatan, fase puncak dan fase penurunan estrus (Gambar 1).

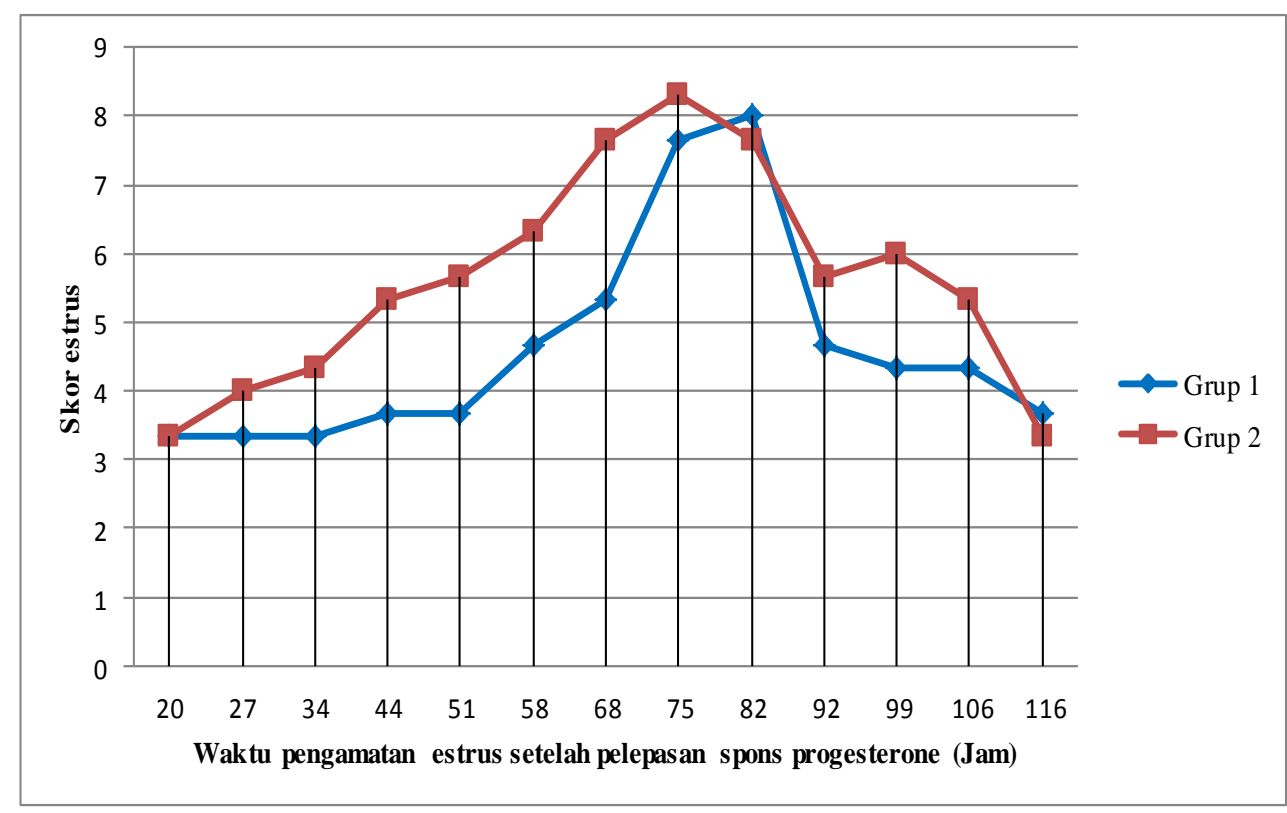

\section{Gambar 1. Penilaian Skor Estrus Setelah Sinkronisasi Estrus Menggunakan Spons Progesterone Intra Vaginal Selama 9 Hari (Grup 1) dan 14 Hari (Grup 2) dengan Suplementasi Zn.}

\section{Temperatur Tubuh Saat Sinkronisasi Estrus}

Berdasarkan hasil pengamatan menunjukkan suhu awal pada kedua Grup masih berada pada suhu normal kambing yaitu $38,4 \pm 0,20{ }^{\circ} \mathrm{C}$ pada Grup 1 dan $38,37 \pm 0,29{ }^{0} \mathrm{C}$ pada Grup 2 . Peningkatan suhu tubuh secara bertahap meningkat seiring pada saat-saat estrus terjadi. 206 
Peningkatan suhu pada saat puncak estrus berkisar pada jam ke-51 hingga 99. Kedua kelompok perlakuan teramati mengalami peningkatan suhu pada rentang waktu terjadinya estrus. Suhu tubuh yang teramati adalah $38,7 \pm 0,20{ }^{\circ} \mathrm{C}$ hingga $39,60 \pm 0,26{ }^{\circ} \mathrm{C}$. Hasil pengamatan temperatur anal Grup implant spons progesterone disajikan pada Tabel 3.

Tabel 3. Suhu Tubuh Setelah Sinkronisasi Estrus Menggunakan Spons Progesterone

\begin{tabular}{ccccccccccccccc}
\hline & \multicolumn{10}{c}{ Suhu tubuh setelah sinkronisasi estrus $\left({ }^{\circ} \mathrm{C}\right)$} \\
\cline { 2 - 12 } & 20 & 27 & 34 & 44 & 51 & 58 & 68 & 75 & 82 & 92 & 99 & 106 & 116 \\
& jam & jam & jam & Jam & jam & jam & jam & jam & jam & jam & jam & jam & jam \\
\hline \multirow{3}{*}{ Grup } & 38,4 & 38,5 & 38,33 & 38,06 & 38,96 & 38,66 & 37,86 & 39,00 & 38,70 & 37,76 & 39,13 & 38,36 & 38,46 \\
1 & $\pm 0,20$ & $\pm 0,20$ & $\pm 0,28$ & $\pm 0,20$ & $\pm 0,23$ & $\pm 0,20$ & $\pm 0,25$ & $\pm 0,26$ & $\pm 0,20$ & $\pm 0,20$ & $\pm 0,25$ & $\pm 0,15$ & $\pm 0,11$ \\
& & & & & & & & & & & & & \\
Grup & 38,37 & 38,7 & 38,63 & 38,50 & 38,90 & 38,70 & 39,10 & 39,47 & 39,13 & 39,17 & 39,60 & 39,23 & 38,5 \\
2 & $\pm 0,29$ & $\pm 0,26$ & $\pm 0,15$ & $\pm 0,35$ & $\pm 0,30$ & $\pm 0,26$ & $\pm 0,20$ & $\pm 0,25$ & \pm 012 & $\pm 0,15$ & $\pm 0,26$ & $\pm 0,25$ & $\pm 0,44$ \\
\hline
\end{tabular}

Gambaran kurva pengukuran suhu pada saat sinkronisasi estrus kambing PE secara keseluruhan mulai meningkat pada jam ke-51. Temperatur tubuh pada kelompok perlakuan 9 hari terlihat naik pada fase puncak estrus (jam ke-75 dan 82) yaitu $39 \pm 0,26{ }^{\circ} \mathrm{C}$ dan $38,7 \pm 0,20{ }^{\circ} \mathrm{C}$. Kedua perlakuan menunjukkan peningkatan pada jam ke-75 selanjutnya bertahan pada kisaran 38,7-39, $6{ }^{\circ} \mathrm{C}$ pada saat mencapai puncak estrus. Suhu tubuh tertinggi pada Grup 1 adalah $39,00 \pm 0,26{ }^{\circ} \mathrm{C}$ sedangkan pada perlakuan 14 hari sebesar $39,60 \pm 0,26{ }^{\circ} \mathrm{C}$ (Gambar 2).

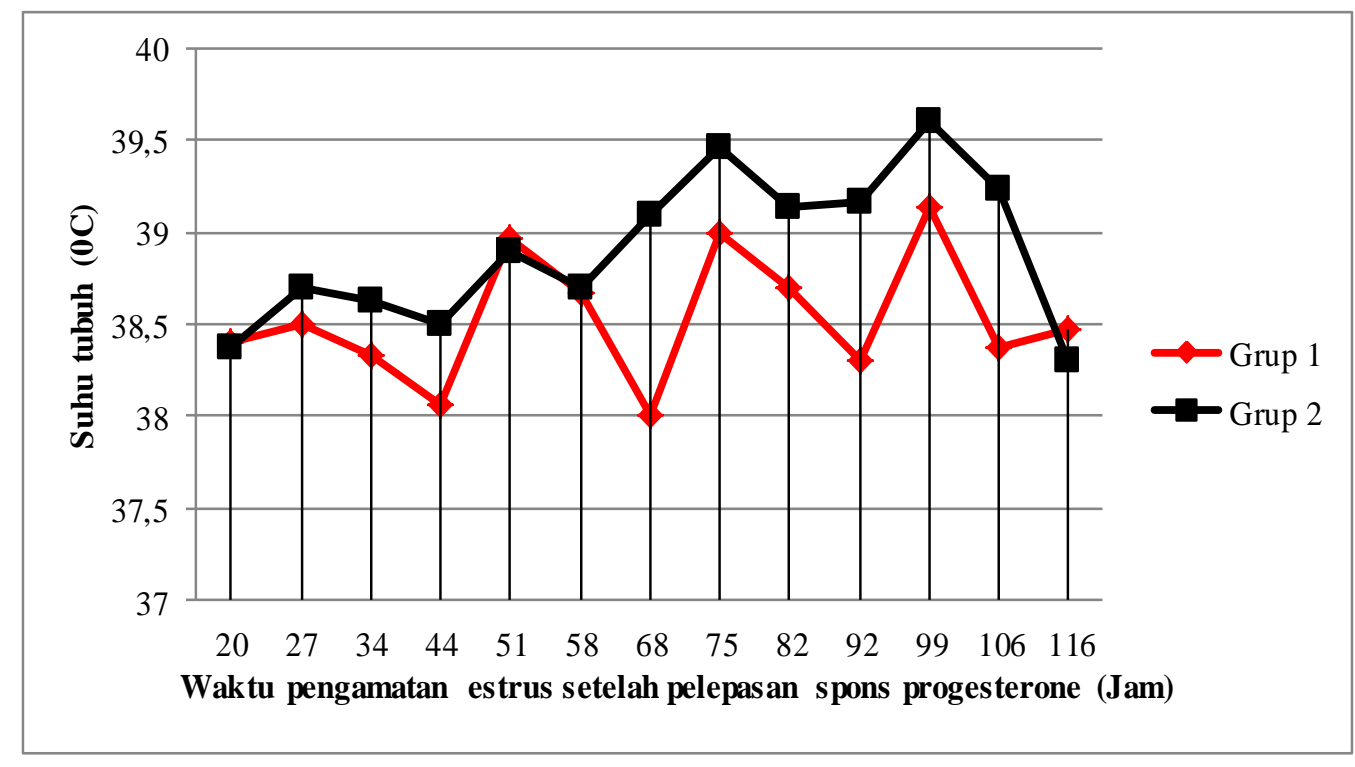




\section{Gambar 2. Suhu Tubuh Setelah Sinkronisasi Estrus Menggunkan Spons Progesterone Intra Vaginal Selama 9 Hari (Grup 1) dan 14 hari (Grup 2) dengan Suplementasi $Z n$.}

Secara umum kedua grup mengalami peningkatan namun Grup 2 sedikit lebih tinggi temperatur tubuhnya dibanding Grup 1. Fase penururnan suhu tubuh pada saat sinkronisasi estrus mulai teramati menurun pada jam 106 hingga jam ke-116. Pengamatan pada kedua Grup menunjukkan suhu tubuh pada saat estrus sudah seperti semula yaitu $38,46 \pm 0,11{ }^{0} \mathrm{C}$ pada Grup 1 dan $38,5 \pm 0,44^{\circ} \mathrm{C}$ pada Grup 2. Peningkatan suhu tubuh yang cenderung meningkat pada beberapa jenis kambing di daerah Rawalpindi, Pakistan juga diungkapkan pada penelitian sinkronisasi estrus menggunakan spons progesterone (Mehmood et al., 2011).

Penelitian sinkronisasi birahi menggunakan metode spons progesterone intra vaginal selama 9 dan 14 hari yang dikombinasikan dengan pemberian suplemen $Z n$ memberikan hasil keseragaman estrus pada kambing PE. Sinkronisasi estrus selama 14 hari menghasilkan nilai maksimal kualitas estrus yang lebih tinggi, urasi estrus pada yang lebih panjang dan onset estrus lebih cepat. Penggunaan implant spons progesterone intra vaginal selama 9 hari memberikan harapan pelaksanaan sinkronisasi estrus lebih efisien. Diperlukan penelitian lanjutan sehingga sinkronisasi estus dapat lebih efektif dan efisien. Secara keseluruhan temperatur badan kambing PE yang estrus cenderung mengalami kenaikan seiring terjadinya estrus.

\section{KESIMPULAN}

Kesimpulan dari penelitian ini adalah pada kedua perlakuan sinkronisasi estrus menggunakan spons progesterone dan suplementasi Zinc dapat menimbulkan estrus secara bersamaan. Nilai maksimal kualitas estrus pada perlakuan 9 hari (Grup 1) adalah 8,0 1,0 lebih

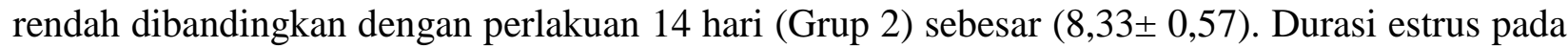
pada Grup 1 (7 jam) lebih pendek dibandingkan Grup 2 (24 jam). Periode onset Grup 1 memerlukan waktu lebih lama (75 jam) dibandingkan Grup 2 (58 jam). Suhu tubuh hewan coba mengalami kenaikan seiring terjadinya estrus.

\section{UCAPAN TERIMA KASIH}

Penulis mengucapkan banyak terimakasih kepada Sekolah Vokasi UGM yang telah memberikan dana hibah penelitian dengan nomor kontrak 116/UN.1.SV/K/2018 melalui Program Studi Kesehatan Hewan, Departemen Teknologi Hayati dan Veteriner. Terimakasih juga penulis 
Muhammad Rosyid Ridlo, Risa Ummami, Naela Wanda Yusria Dalimunthe, Dhasia Ramandani, Nur Ika Prihanani, Morsid Andityas, Tri Satya Mastuti Widi Profil Vulva Dan Suhu Tubuh Kambing Peranakan Etawa pada Sinkronisasi Estrus Menggunakan Medroxy Progesterone Acetate dan Suplementasi Zinc (Zn)

sampaikan kepada Teguh, Hakim, Nawang, Meta dan Riza yang telah banyak membantu dalam penelitian ini.

\section{DAFTAR PUSTAKA}

Adriani, A., Sutardi, T., Sutama, I.K., dan Manalu, W. 2004. Pengaruh Superovulasi dan Suplementasi Mineral Seng dalam Ransum pada Induk kambing terhadap Pertumbuhan Anaknya. J. Indon. Trop. Anim. Agric.29(4).(177-183).2004.

Cochran P.E. 2011. Veterinary Anatomy and Physiology: A Clinical Laboratory Manual (2 $2^{\text {nd }}$ ed). New York. USA : Delmar. Cengage Learning, (Chapter 14).

Kawu, M., Lakpini, C., Ayo, J., Fatihu, M., Yaqub, L., Habibu, B., Shittu, M., Aluwong, T., and Ambali, S. 2015. Influence of Season and Oestrous Cycle Phase on Serum Progesterone and Thyroxine Profiles in Savanna Brown Goats. IOSR Journal of Agriculture and Veterinary Science (IOSR-JAVS). e-ISSN: 2319-2380, p-ISSN: 2319-2372. Volume 8, Issue 12 Ver. I (Dec. 2015), PP 15-22.

Kurniasih, N.N., Fuah, A.M., dan Priyanto, R. 2013. Karakteristik Reproduksi dan Perkembanga Populasi Kambing peranakan Etawah di Lahan Pasca Galian Pasir

Machiya, P., Sarmah, B.K., Chakravarty, P., Biswas, R.K., Sarmah, B.C., and Deka, B.C. 2011. Reproductive Performances in Goat Following Synchronization if Oestrus iith Progesteroneimpregnated Vaginal Sponge ind Gonadotropin. Indian J. Anim. Res., 4646 (3) : $258-262,2012$.

Mehmood, A., Andrabi, S.M.H., Anwar, M., and Rafiq, M. 2011. Estrus Synchronization and Artificial Insemination in Goats during Low Breeding Season-A Preliminary Study. Pak Vet J, 2011, 31(2): 157-159.

Ridlo, M.R., Budiyanto A., Yuriadi. 2015. Kajian Aplikasi Hormon Gnrh dan Suplementasi Seng Terhadap Litter Size Kambing Ras Campuran. Tesis. Program Studi Magister Sain Veteriner. Fakultas Kedokteran Hewan. Universitas Gadjah Mada. Yogyakarta.

Siregar, T.N. 2009. Estrogen and Progesterone Profile in Aceh Local Goat Estrous Cycle. J. Ked. Hewan Vol. 3 No. 2 September 2009

Zaenuri, L.A dan Rodiah. 2016. Efektifitas Progesteron Kering dan Basah Sebagai Perangsang Birahi Ternak Kambing. Jurnal Ilmu dan Teknologi Peternakan Indonesia Volume 2 (1): 129 133; Juni 2016. 